\section{Oppdatert om kreft på norsk}

Kåresen R, Wist E, red.

\section{Kreftsykdommer}

En basisbok for helsepersonell. 3. utg. $441 \mathrm{~s}$, tab, ill. Oslo: Gyldendal Akademisk, 2009.

Pris NOK 585

ISBN 978-82-05-38485-9

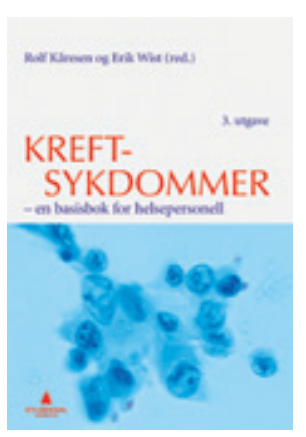

Nå kommer ny utgave av en meget ettertraktet bok. 1. utgave kom $\mathrm{i}$ år 2000. Rask medisinsk og teknologisk utvikling innen feltet ga behov for ny utgave i 2004. Denne inneholdt de nødvendige oppdateringer og bygde

for øvrig i hovedsak på forrige utgave.

3. utgave er altså klar. Den er topp oppdatert, både på utredning, behandling og oppfølging av de aller fleste kreftsykdommer.

Boken er på norsk og dermed meget godt tilgjengelig. Språket er lett, tydelig og faktapreget. Den er systematisk lagt opp, tar for seg organområder i rekkefølge og belyser de fleste undergrupper av krefttyper i hvert organfelt.

Hvert kapittel er bygd opp med beskrivelse av kreftform, forekomst og utbredelse samt stadieinndeling. Deretter omtales symptomer, utredning og diagnostisering, behandling, oppfølging og etterkontroller samt prognose.

Forfatterne går igjennom nye behandlingsformer, alternativ behandling og viktig informasjon som bør formidles til pasienten. Pasienten presenteres som et helt menneske, med de behov dette medfører.

Leseren kan gå direkte inn i faktaboksene for å finne konkret informasjon, i tillegg til at det er mange, gode og informative bilder av tilstander.

Målgruppen er allmennleger og andre i sektoren som har behov for lett tilgjengelig og oppdatert informasjon. I tillegg vil den være et godt læreverk for studenter.

Denne boken er vel verdt investeringen og egner seg på ethvert legekontor.

Ellen B. Pedersen

$\emptyset$ ksnes legekontor

Myre i Vesterålen

\section{Koffert for nevromotorisk testing av barn og unge}

Andrup G, Gjærum B, Janson H. NUBU 4-16

Nevromotorisk unders $\emptyset$ kelse for barn og ungdom fra 4 til 16 år. 164 s, ill. Oslo: Universitetsforlaget, 2008. Pris NOK 5990 ISBN 978-82-15-01225-4

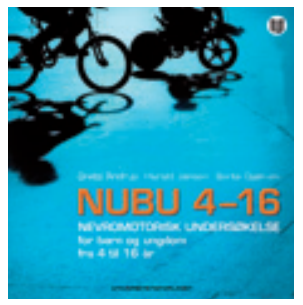

$N U B U 4-16$ er et testbatteri for motoriske ferdigheter og tvetydige nevrologiske tegn (soft neurological signs) hos barn og unge 4-16 år. Slike tester er et viktig

tilleggsredskap for å avdekke subtile nevromotoriske avvik og har lenge vært benyttet av leger og tverrfaglig personell $\mathrm{i}$ blant annet barne- og ungdomspsykiatrien og habiliteringstjenesten, men man har savnet norske normer.

Forfatterne har gjort et stort arbeid for normering av denne testen. NUBU 4-16 er basert på undersøkelse av 272 antatt friske barn i Oslo. Forfatterne har satt en grense for patologi ved de laveste $15 \%$ skår for normalbefolkningen ved de ulike alderstrinnene.

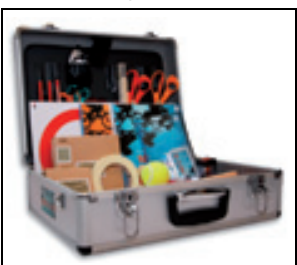

Målgruppen for dette testbatteriet er alle faggrupper som utreder nevromotorisk funksjonsnivå hos barn og unge. Forfatterne anbefaler sterkt at de som skal bruke testen deltar på kurs og at de uansett diskuterer de kliniske funnene med lege.

NUBU 4-16 består av tre deler: test av tvetydige nevrologiske tegn, motorisk test og beskrivelse av nevrologisk legeundersøkelse. Kofferten med testutstyr inneholder to bøker (testmanual og dokumentasjon), DVD, skåringsskjema og utstyr som sakser, stoppeklokke, målebånd o.1.

Det gjennomgås historikk og referanser for både tidligere tester og for denne. Referanselisten er fyldig og er hentet fra tidsskrifter innen barnemedisin, psykiatri, psykologi og fysioterapi. Språket er godt og lettlest i begge bøkene. Testmanualen er tydelig i oppgaver, hva som skal observeres og mål for undersøkelsene, og den er også bruksvennlig innbundet.

Det vedlagte skåringsprogrammet på
DVD for de motoriske oppgavene er nyttig. Instruksjonene er gode, med behagelig filming, tydelige instruktører og akseptabel lyd. Undertegnede savner en noe bedre skriftlig forklaring av testene, eventuelt en sidehenvisning til manualen for den aktuelle testen. Beskrivelsen av øvelsen og av alderstrinnet forsvinner for raskt i bildet. Jeg savner også en lenke fra den aktuelle testen på DVD til både dokumentasjon og manual, slik at man raskt kunne fordypet seg.

Musikken som angir pauser og emneskifte på DVD-en, har et komisk preg som gir assosiasjoner til «tøy og bøy» på NRK radio fra tidligere dager. Bøkene inneholder mange skrivefeil og en del feilbruk av medisinsk terminologi. Det sistnevnte gjør at man får inntrykk av at leger ikke er hovedmålgruppen. Det er synd, for testbatteriet kan være et viktig redskap for leger som utreder barn med utviklingsforstyrrelser. Testen bør finnes ved institusjoner som tverrfaglig utreder barn og unge med utviklingsavvik innen de aktuelle områder. Prisen på nesten 6000 kroner synes høy, spesielt med tanke på at man anbefaler kurs for å lære bruken av testene.

\section{Einar Bryne}

Habiliteringssenteret

Sykehuset i Vestfold

Tønsberg

\section{Praktisk håndbok om rettigheter}

Hotvedt M, Syse A.

\section{Barn ventes}

Rettigheter for småbarnsforeldre. 173 s, ill. Oslo: Gyldendal Akademisk, 2009. Pris NOK 320 ISBN 978-82-05-38961-8

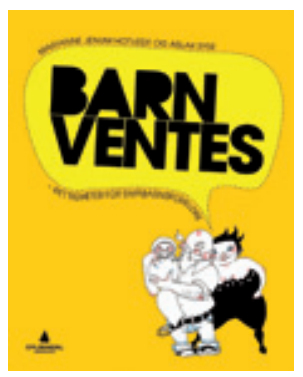

Målgruppen er vordende og nybakte småbarnsforeldre, og rettigheter fra svangerskapet og gjennom barnets tre første leveår blir omtalt. Forfatterne er juridiske eksperter i det aktuelle fagfeltet og benytter også egne erfaringer som foreldre. Boken er oppdatert i forhold til aktuelle lovverk og stønadssatser fra januar 2009. 